\title{
Effect of Sex Hormone Binding Globulin on the Development of Ovarian Cancer in a Mouse Model
}

\author{
Janina Baranowska-Kortylewicz ${ }^{*}$, Jessica Nearman and Zbigniew P. Kortylewicz
}

Department of Radiation Oncology, University of Nebraska Medical Center, J. Bruce Henriksen Cancer Research Laboratories, 986850 Nebraska Medical Center, Omaha, Nebraska 68198-6850, USA

\begin{abstract}
Sex hormone-binding globulin (SHBG) is the major carrier protein of testosterone and estradiol in the blood. Although studies on the role of SHBG in ovarian cancer are inconclusive, substantial evidence indicates that SHBGsteroid complexes can play a direct role in the intracellular transport of steroids to cancer cells. SHBG is synthesized in the adult liver of many species, excluding rodents. Adult mouse and rat livers do not produce SHBG, and yet most experimental models of ovarian cancer employ these species. Data reported here indicate that SHBG has a major stimulatory effect on the growth of human ovarian cancer in athymic mice. The effect is observed in subcutaneous and intraperitoneal OVCAR-3 xenografts. Tumor doubling times were 9.98 \pm 0.14 days and 17.20 \pm 0.64 days when OVCAR-3 cells were implanted with and without SHBG, respectively $(P=0.023)$. The magnitude of SHBG effect depended on the age of mice and it was most prominent in the development of intraperitoneal solid tumor deposits. Levels of circulating CA-125 were also age- and tumor size-dependent. Biodistribution studies of ${ }^{125} \mathrm{I}$-SHBG indicated a prolonged retention of the protein in solid tumor deposits. Estimated half-lives of ${ }^{125} \mathrm{I}$-SHBG were $2.3 \times$ longer in solid tumors as compared to nonadherent cancer cells in the peritoneal lavage. The normal tissue distribution of ${ }^{125} \mathrm{I}-\mathrm{SHBG}$ was similar in control and OVCAR-3-bearing mice. These data suggest that currently used models of ovarian cancer in mice, including carcinogenesis and drug evaluation studies, are imperfect because of the lack of SHBG production in these species.
\end{abstract}

\section{INTRODUCTION}

Most of the attention in assessing the role of SHBG in carcinogenesis is focused on its ability as a carrier protein to regulate the bioavailability of testosterone in prostate cancer $[1,2]$. Recent evidence suggests that SHBG, independent of its role as a carrier protein [2,3], has a more complex function in cell signaling by direct binding to its receptor, inducing synthesis of cAMP and initiating downstream signaling [4-7].

The role of SHBG in ovarian cancer is largely undefined. Population-based case-control studies found no links between several genetic variants of SHBG and ovarian cancer risk [8]. No association between serum levels of SHBG and ovarian cancer risk was identified [9, 10]. Nevertheless, the pathophysiology of ovarian cancer supports a strong connection with androgens. It is still unclear, which of the hormone-regulated mechanisms are critical in the pathogenesis of ovarian cancer $[11,12]$. It is possible that the receptor-mediated action of SHBG serves as an additional control mechanism, which alters the effects of sex hormones in cancer cells. It is of great interest from the standpoint of clinical applications that in some cancers SHBG levels in blood are inversely associated with cancer risk $[13,14]$. SHBG bound to the membrane of breast cancer MCF-7 cells can inhibit the estradiol-induced cell proliferation $[15,16]$. In contrast, the growth of human

*Address correspondence to this author at the Department of Radiation Oncology, University of Nebraska Medical Center, J. Bruce Henriksen Cancer, Research Laboratories, 986850 Nebraska Medical Center, Omaha, Nebraska 68198-6850, USA; Fax: 402-559-9127; Tel: 402-559-8906; E-mail: jbaranow@unmc.edu prostate cancer ALVA-41 cells is stimulated by dihydrotestosterone and estradiol only in the presence of SHBG [7].

The investigation of these uncertainties of SHBG effects on the cancer development and the potential role of SHBG in the clinical management of cancer is complicated by the fact that in vivo studies are typically conducted in mice. Livers of most adult mammals secrete SHBG into the blood, where it circulates as the major sex hormone binding protein. In rodents, adult livers do not produce SHBG and as a result, the amounts of circulating SHBG are virtually undetectable. This deficiency of the mouse model has a significant negative impact on the progress of studies to define the SHBG biological activity as well as the drug evaluation studies [17]. Although a transgenic mouse able to secrete human SHBG has been generated [18], little is known about the susceptibility of this animal to cancer. In studies reported herein, we have established the stimulatory effect of human SHBG on the growth of androgen receptor-positive human ovarian cancer OVCAR-3 cells in athymic mice.

\section{MATERIALS AND METHODOLOGY}

\section{Reagents, Buffers and General Procedures}

SHBG was purchased from Lee Biosolutions, Inc. (St. Louis, MO). RPMI-1640 medium was from GIBCO $^{\circledR}$ Invitrogen Cell Culture (Carlsbad, CA). $\left[{ }^{125} \mathrm{I}\right] \mathrm{NaI}$ in $1 \times 10^{-5}$ $\mathrm{NaOH}$ ( $\mathrm{pH}$ 8-11) was obtained from PerkinElmer (Waltham, MA). Radioactivity was measured with Minaxi $\gamma$-counter (Packard, Waltham, MA), a dose calibrator (Capintec Inc., Ramsey, NJ), and for the HPLC effluent with the sodium iodide crystal Flow-count detector (Bioscan, Washington, DC) connected in-line with the UV detector. Variable 
wavelength detectors UVIS-205 (Linear, Irvine, CA) and UV-116 (Gilson, Middleton, WI) were used. Quality control analyses of radiolabeled protein were done on TSK-GEL3000SW column $(7.5 \mathrm{~cm} \times 30 \mathrm{~cm}$, Tosohaas, Montgomeryville, PA) with $0.1 \mathrm{M}$ sodium phosphate, $0.1 \mathrm{M}$ sodium sulfate, $\mathrm{pH} 7.3$ as the eluant, and the SDS-PAGE electrophoresis on precast Ready Gel Tris- $\mathrm{HCl}$ (4-20\% resolving gel, $4 \%$ stacking gel, 10 -well, $30 \mu 1,8.6 \times 6.8 \mathrm{~cm}$, Hercules, CA). Cancer Antigen CA-125 EIA kit was purchased from Panomics, Inc. (Fremont, CA).

\section{Mice}

Athymic NCr- $n u / n u$ mice were from the National Cancer Institute at Frederick (Frederick, MD). Mice were allowed to acclimate for no less than 5 days after arrival to the UNMC facilities. All protocols involving mice were approved by the UNMC Institutional Animal Care and Use Committee.

\section{In vitro Cell Survival Assay}

OVCAR-3 cells were plated in a 96-well plate at 3,000 cells/well and allowed to attach for $24 \mathrm{~h}$. Medium was removed and replaced with fresh medium containing 0 $\mu \mathrm{g} / \mathrm{mL} \quad(\mathrm{n}=24), 10 \mu \mathrm{g} / \mathrm{mL} \quad(\mathrm{n}=18)$ and $100 \mu \mathrm{g} / \mathrm{mL} \quad(\mathrm{n}=18)$ SHBG. After $48 \mathrm{hrs}$ in culture, spent medium was removed and cell proliferation was determined using CellTiter $96^{\circledR}$ AQueous One Solution Cell Proliferation Assay (Promega, Madison, WI). Optical density at $492 \mathrm{~nm}$ was read using Opsys MR ${ }^{\mathrm{TM}}$ 96-well microplate reader (Dynex Technologies, Chantilly, VA).

\section{Radioiodination of SHBG}

SHBG was radioiodinated using the Iodogen method [19]. All radioiodinations were performed on site as follows: into a glass test tube coated with $0.1 \mathrm{mg}$ of $1,3,4,6-$ tetrachloro-3 $\alpha, 6 \alpha$-diphenylglycouril (Iodogen; SigmaAldrich, St. Louis, MO) was added $0.2 \mathrm{~mL}$ of $0.1 \mathrm{mg} / \mathrm{mL}$ SHBG in PBS, pH 7.2 and $0.01 \mathrm{~mL}$ of iodine-125 ( 1.2 mCi; $44 \mathrm{MBq}$ ). The mixture was incubated at room temperature for 10-15 min. The reaction progress was measured using instant thin layer chromatography with ethanol/PBS (1: 9; $\mathrm{v} / \mathrm{v}$ ) as the elution system. ${ }^{125} \mathrm{I}-\mathrm{SHBG}$ was purified on a 2$\mathrm{mL}$ Zeba Desalt Spin column (Pierce Biotechnology, Rockford, IL). Typically, ${ }^{125} \mathrm{I}-\mathrm{SHBG}$ was obtained in $\sim 50 \%$ radiochemical yield and the specific activity of $\sim 30 \mathrm{mCi} / \mathrm{mg}$. Before administration, ${ }^{125} \mathrm{I}-\mathrm{SHBG}$ was diluted in $0.01 \mathrm{M}$ phosphate buffer, $\mathrm{pH} 7.2$ at $25^{\circ} \mathrm{C}, 0.0027 \mathrm{M}$ potassium chloride and $0.137 \mathrm{M}$ sodium chloride (PBS) containing $0.1 \%$ mouse serum (Sigma-Aldrich, St. Louis, MO) to yield the injection dose volume of $0.3 \mathrm{~mL}$ per mouse. Triplicate standards equivalent to $0.001 \mathrm{~mL}$ of the injected dose were prepared in $0.1 \mathrm{~mL} \mathrm{PBS} / 0.1 \%$ mouse serum and counted in a $\gamma$-counter alongside the necropsy samples.

\section{Biodistribution of ${ }^{125}$ I-SHBG}

Athymic NCr-nu/nu female mice were injected intraperitoneally (IP) with OVCAR-3 cells propagated as the IP xenografts. Cells were injected in $0.4 \mathrm{~mL}$ of serum-free RPMI-1640 medium. Six weeks later mice received IP injection of ${ }^{125} \mathrm{I}-\mathrm{SHBG}$ in $0.3 \mathrm{~mL}$ PBS containing $0.1 \%$ mouse serum. The average injected dose was $13.4 \pm 0.6 \mu \mathrm{Ci}$
$(0.5 \pm 0.02 \mathrm{MBq})$. Mice were killed $1 \mathrm{~h}$ and $24 \mathrm{~h}$ after ${ }^{125} \mathrm{I}-$ SHBG injection. Mice without tumors injected with ${ }^{125} \mathrm{I}-$ SHBG were used as controls.

\section{OVCAR-3 Xenografts}

Intraperitoneal model: athymic NCr-nu/nu female mice aged approximately 2, 6 and 12 months received IP implants of $1 \times 10^{7}$ OVCAR- 3 cells either with SHBG or without. Mice were observed two times per week until first visible tumors were detected. From this point, mice were weighed 2-3 times per week and the presence of tumors was noted. The experiment was terminated when the estimated tumor burden reached $\sim 10 \%$ body weight.

Subcutaneous (SQ) model: athymic 6-8 weeks old NCr$n u / n u$ female mice received SQ injection of $5 \times 10^{6}$ OVCAR3 cells in $0.1 \mathrm{~mL}$ PBS supplemented with SHBG. Control mice received identical inoculum of OVCAR-3 cells in PBS but without SHBG. Mice were observed two times per week until measurable tumors developed. From this point, SQ xenografts were measured 2 times per week. The experiment was terminated when the estimated tumor burden reached $\sim 10 \%$ body weight.

\section{Necropsy}

Mice were euthanized according to the AVMA guidelines [20]. Blood was collected via a cardiac puncture. Hematocrit was determined by standard techniques. HemoCue $^{\circledR}$ was used to measure hemoglobin levels (Ängelholm, Sweden). The remaining whole blood was used to prepare serum without additives, as required for the determination of CA-125. Serum was stored at $-80^{\circ} \mathrm{C}$ until use. The peritoneal cavity was lavaged with $2 \mathrm{~mL}$ PBS to recover nonadherent OVCAR-3 cells and ascites. Tissues were dissected, rinsed in PBS and their wet weight was determined. For the biodistribution studies, dissected tissues were placed in $\gamma$-counter tubes and their radioactive content was determined.

\section{CA-125 Measurements}

Serum prepared from a whole blood specimen without additives was stored at $-80^{\circ} \mathrm{C}$ until ready to use. All reagents and serum were brought to room temperature and the protocol provided with the kit was followed. Standard curves were constructed using the reference standard set provided with the kit. Optical density at $450 \mathrm{~nm}$ was read using Opsys MR $^{\mathrm{TM}}$ 96-well microplate reader (Dynex Technologies, Chantilly, VA).

\section{Statistical Analyses}

Summary statistics were performed using a two-sided, unpaired Student's t-test with a significance level of $\mathrm{P}=0.05$. Tumor doubling times $\left(\mathrm{T}_{\mathrm{D}}\right)$ were calculated using the curve fitting function of SigmaPlot/SigmaStat (Systat Software, Inc. Point Richmond, CA).

\section{RESULTS}

\section{In vitro Studies}

The in vitro growth of OVCAR-3 cells did not appear to be influenced by SHBG. The quantity of formazan product, 
which is directly proportional to the number of living cells and is measured by the amount of $492 \mathrm{~nm}$ absorbance, did not indicate any notable changes in the OD in cells treated with SHBG compared to untreated controls. At the highest concentration of SHBG $(0.1 \mathrm{mg} / \mathrm{mL})$, only $\sim 3 \%$ more growth was observed compared to OVCAR-3 cells grown in medium without SHBG and this increase was within the experimental error. OD values were as follows: $0.469 \pm 0.011$, $0.475 \pm 0.011$, and $0.482 \pm 0.009$ for $0,0.01$, and $0.1 \mathrm{mg}$ $\mathrm{SHBG} / \mathrm{mL}$ medium, respectively.

\section{Subcutaneous OVCAR-3 Xenografts}

Only three out of five mice implanted SQ with OVCAR3 cells in PBS developed SQ OVCAR-3 tumors whereas during the same period all mice injected with OVCAR-3 cells in PBS containing $0.01 \mathrm{mg}$ SHBG developed SQ tumors. Tumors in PBS group were also significantly smaller. The average tumor weights at necropsy were $0.21 \pm 0.07 \mathrm{~g}$ and $0.56 \pm 0.11 \mathrm{~g}$ in PBS and SHBG groups, respectively.

\section{Intraperitoneal OVCAR-3 Xenografts}

OVCAR-3 cells implanted IP in medium containing SHBG developed tumors approximately twice as fast as tumors implanted without SHBG. Tumor doubling times estimated from the tumor growth curves were $9.98 \pm 0.14$ days and 17.24 \pm 0.64 days, when OVCAR-3 cells were injected with SHBG and PBS, respectively (Fig. (1)). The accelerated growth rate of OVCAR-3 tumors in SHBGtreated mice was also evident from the necropsy data shown in Table $\mathbf{1}$ and Fig. (2). The average total tumor burden in PBS-treated mice was $2.72 \pm 0.50 \mathrm{~g}$ (median $2.39 \mathrm{~g}$ ) compared to $4.01 \pm 0.58 \mathrm{~g}$ (median $3.89 \mathrm{~g}$ ) in SHBG-treated animals, calculated collectively for all age groups. This

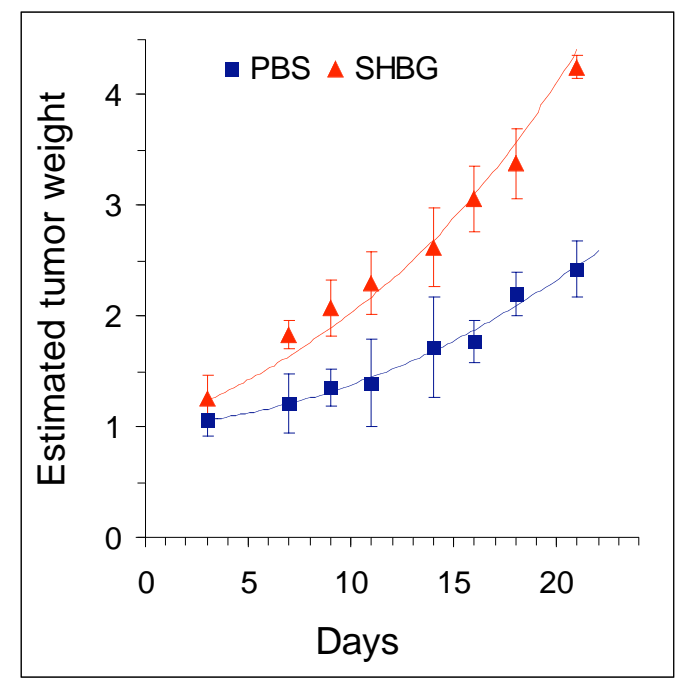

Fig. (1). Intraperitoneal OVCAR-3 tumor growth curves. Tumor weights were estimated from the increase of the total body weight relative to the body weight 38 days after the OVCAR-3 implant when mice begun to develop palpable tumors (day 0). OVCAR-3 co-injected with SHBG (triangles) develop IP tumors faster with the estimated doubling time $T_{D}=9.98 \pm 0.14$ days. Control mice injected with OVCAR-3 and PBS (squares), in place of SHBG, develop slower with $\mathrm{T}_{\mathrm{D}}=17.20 \pm 0.64$ days. difference derives primarily form the solid tumor burden (Table 1). Effects of SHBG on the growth of nonadherent OVCAR-3 cells collected with the IP lavage was less pronounced. The average cell pellet weight in PBS mice was $1.64 \pm 0.48 \mathrm{~g}$ compared to $1.83 \pm 0.19 \mathrm{~g}$ in SHBG-treated mice and this difference was not statistically significant.

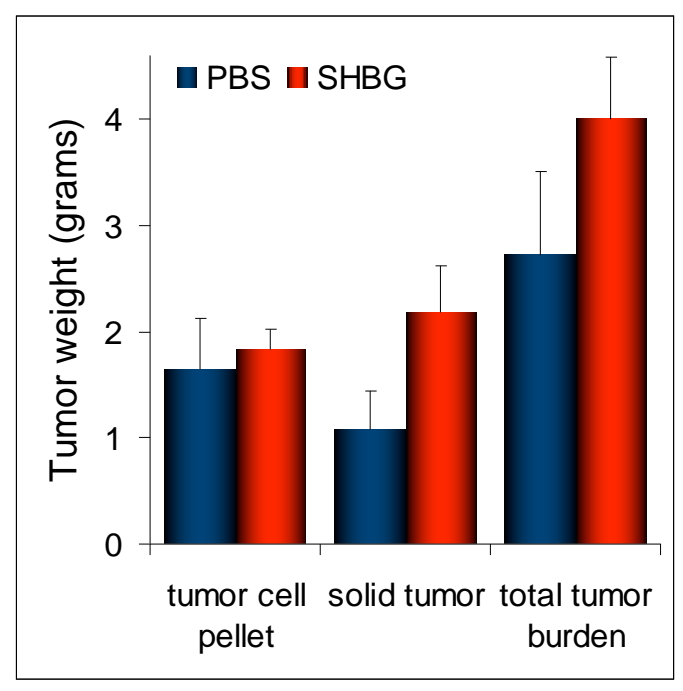

Fig. (2). Average total tumor burden calculated collectively for all age groups in a given treatment scheme. Color bar represents the average tumor weight; the line is sem.

Six weeks after the OVCAR-3 implant, several mice in SHBG group were euthanized. The rapid increase in their body weights and distended abdomen indicated rapidly growing OVCAR-3 tumors and ascites. The necropsy revealed that in addition to copious ascites containing nonadherent tumor cells, large peritoneal deposits of solid tumors also formed. Multiple mesenteric tumors were observed along the entire length of the intestine. The intestine was not perforated. In most mice, large pancreatic tumors associated with the pyloric node and many smaller solid tumor nodules associated with renal, mesenteric, and lumbar or sacral lymph nodes were observed. Sporadically, when the solid tumor burden was $>3 \mathrm{~g}$, both ovaries and uterus were also invaded. A similar tumor distribution was observed in the PBS-treated mice; however, solid tumor nodules were fewer and significantly smaller.

All mice in the SHBG group had copious ascites containing abundance of nonadherent cancer cells and frequent solid tumors. In contrast, in the PBS group, the overall tumor burden was much less and $20 \%$ of mice did not develop measurable OVCAR-3 tumors within the time frame of this study. OVCAR-3 cells exhibited the least aggressive behavior in the 58-days old mice and on an average, tumors took two weeks longer to reach the size similar to tumors in mice 207 days or 361 days of age at time of the OVCAR-3 implant (Table 2).

The difference in the growth of OVCAR-3 and its dependence on the animal age were also reflected in the levels of circulating CA-125 (Fig. (3)). Elevated CA-125 levels were observed in all mice bearing OVCAR-3 xenografts as compared to control mice without OVCAR-3 implants. Normal healthy mice do not have any measurable CA-125 in serum. Mice implanted with OVCAR-3 cells co- 
Table 1. Weight of OVCAR-3 Xenografts Collected at Necropsy in Mice Treated with either PBS (Control) or SHBG. Cancer Cell Pellets were Collected in a Peritoneal Lavage. Solid Tumors were Dissected during Necropsy. (Average Tumor Weights in grams and (sem) are Listed)

\begin{tabular}{|c|c|c|c|c|c|c|c|}
\hline $\begin{array}{c}\text { Mice Age } \\
\text { at Implant (days) }\end{array}$ & Treatment & $\begin{array}{l}\text { Cancer Cell } \\
\text { Pellet (g) }\end{array}$ & $\begin{array}{c}\text { Pvalue } \\
\text { PBS vs. SHBG }\end{array}$ & $\begin{array}{c}\text { Solid } \\
\text { Tumor }(\mathrm{g})\end{array}$ & $\begin{array}{c}\text { Pvalue } \\
\text { PBS vs. SHBG }\end{array}$ & $\begin{array}{c}\text { Total } \\
\text { Tumor }(\mathrm{g})\end{array}$ & $\begin{array}{c}\text { Pvalue } \\
\text { PBS vs. SHBG }\end{array}$ \\
\hline \multirow{2}{*}{58} & PBS & $\begin{array}{c}1.34 \\
(0.42)\end{array}$ & \multirow{2}{*}{0.139} & $\begin{array}{c}0.95 \\
(0.29)\end{array}$ & \multirow{2}{*}{0.002} & $\begin{array}{c}2.28 \\
(0.67)\end{array}$ & \multirow{2}{*}{0.011} \\
\hline & SHBG & $\begin{array}{c}1.95 \\
(0.05)\end{array}$ & & $\begin{array}{c}2.39 \\
(0.22)\end{array}$ & & $\begin{array}{c}4.34 \\
(0.20)\end{array}$ & \\
\hline \multirow{2}{*}{207} & PBS & $\begin{array}{c}2.29 \\
(1.89)\end{array}$ & \multirow{2}{*}{0.692} & $\begin{array}{c}1.92 \\
(1.18)\end{array}$ & \multirow{2}{*}{0.689} & $\begin{array}{c}4.21 \\
(2.85)\end{array}$ & \multirow{2}{*}{0.972} \\
\hline & SHBG & $\begin{array}{c}1.67 \\
(0.68)\end{array}$ & & $\begin{array}{c}2.64 \\
(1.46)\end{array}$ & & $\begin{array}{c}4.31 \\
(1.99)\end{array}$ & \\
\hline \multirow{2}{*}{361} & PBS & $\begin{array}{c}1.44 \\
(0.23)\end{array}$ & \multirow{2}{*}{0.162} & $\begin{array}{c}0.14 \\
(0.03)\end{array}$ & \multirow{2}{*}{0.016} & $\begin{array}{c}1.58 \\
(0.26)\end{array}$ & \multirow{2}{*}{0.028} \\
\hline & SHBG & $\begin{array}{c}1.85 \\
(0.18)\end{array}$ & & $\begin{array}{c}1.20 \\
(0.31)\end{array}$ & & $\begin{array}{c}3.05 \\
(0.48)\end{array}$ & \\
\hline
\end{tabular}

injected with SHBG had significantly higher serum concentrations of CA-125 compared to PBS-treated mice. For example, in 361-days old mice, when OVCAR-3 cells were injected with PBS CA-125 at necropsy was $251 \pm 17$ U/mL whereas when OVCAR-3 was co-injected with SHBG CA-125 levels were at $402 \pm 47 \mathrm{U} / \mathrm{mL}(P=0.012)$, i.e., $60 \%$ higher. The amount of CA-125 was at the lowest level in the 58-days old mice bearing OVCAR-3 tumors when cells were implanted with PBS in place of SHBG and in this age group, CA-125 levels were not statistically different from the SHBG-treated tumors (Fig. (3); $P=0.242$ ).

Table 2. Percent of Mice with Palpable Tumors and Ascites at 45 Days and 54 Days after the IP Implant of OVCAR-3 Cells

\begin{tabular}{|c|c|c|}
\hline \multirow[b]{2}{*}{ mice age } & \multicolumn{2}{|c|}{ Days after IP OVCAR-3 implant } \\
\hline & 45 & 54 \\
\hline \multicolumn{3}{|l|}{ PBS } \\
\hline 361 days & $50 \%$ & $*$ \\
\hline 207 days & $67 \%$ & $67 \%$ \\
\hline 58 days & $0 \%$ & $0 \%$ \\
\hline \multicolumn{3}{|l|}{ SHBG } \\
\hline mice age & 45 & 54 \\
\hline 361 days & $100 \%$ & $*$ \\
\hline 207 days & $75 \%$ & $75 \%$ \\
\hline 58 days & $0 \%$ & $100 \%$ \\
\hline
\end{tabular}

*All mice in this age group were killed on day 45 .

Although tumors were larger in younger animals (Table (1)), the magnitude of the SHBG effect on the growth of IP OVCAR-3 in 58-days- versus 361-days-old mice is similar, i.e., at necropsy, the total tumor burden in SHBG-treated mice was $\sim 1.9 \times$ larger compared to PBS-treated tumors (Fig. (4); bars labeled total). However, this effect of SHBG did not hold in the "middle age" mice (age 207 days on the day of OVCAR-3 implant). In this group of mice, there was more variability in the tumor development, which was also less dependent on the treatment. The average solid tumor weight at necropsy was $1.92 \pm 1.18 \mathrm{~g}$ and $2.64 \pm 1.46 \mathrm{~g}$ in PBS and SHBG groups, respectively in mice aged 207 days on the day of OVCAR-3 implant (Table 1). CA-125 levels in these mice, however, differed significantly between SHBG- and PBS-treated groups (Fig. (3)). Serum of PBS-treated mice in this age group contained $383 \pm 69 \mathrm{U}$ CA-125/mL, whereas SHBG-treated mice had CA-125 levels at $550 \pm 23 \mathrm{U} / \mathrm{mL}$ (Fig. (3)).

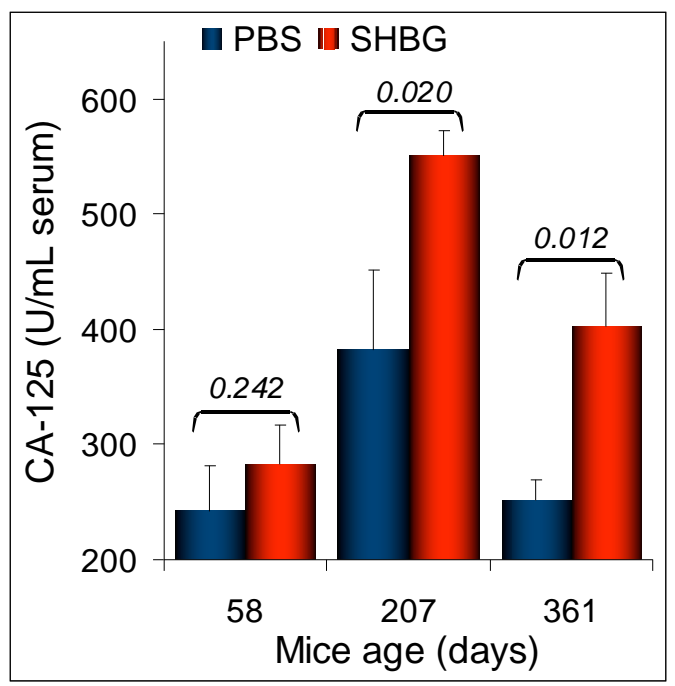

Fig. (3). Effects of SHBG on OVCAR-3 tumor development in 2, 6, and 12 months old mice as reflected by the Cancer Antigen 125 (CA-125) levels in serum. OVCAR-3 tumors were implanted IP at the indicated age of the animal. Serum was prepared from whole blood specimen without additives. Co-injection of SHBG significantly increases levels of CA-125 in serum. Numbers in italics above the bars represent $\mathrm{P}$ values for a two-tailed, homoscedastic Student's t-test for comparison of PBS to SHBG means. 


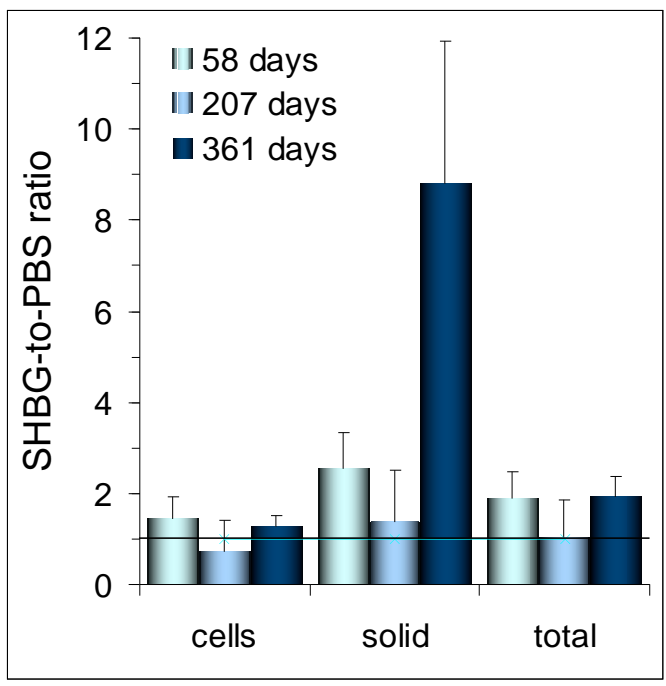

Fig. (4). Differences between IP OVCAR-3 tumor development expressed as the ratio of the tumor weights lavaged (cells) and dissected during necropsy (solid tumor) in SHBG-treated mice to PBS-treated control mice on the day of necropsy. Ratios calculated for the total tumor burden is also shown.

\section{Biodistribution of ${ }^{125}$ I-SHBG in OVCAR-3-Bearing Mice and Control Mice}

The radioiodination of SHBG with ${ }^{125} \mathrm{I}$ was carried out using the Iodogen method. The purification on a Zeba column produced ${ }^{125} \mathrm{I}$-SHBG in $\sim 50 \%$ radiochemical yield and the specific activity of $30 \mathrm{mCi} / \mathrm{mg}$. Fig. (5) shows the quality control data for ${ }^{125} \mathrm{I}$-SHBG. The HPLC analyses were done on the size exclusion column. The red HPLC trace is the output from the radioactivity detector. The black line is the output from the UV detector connected in series. The

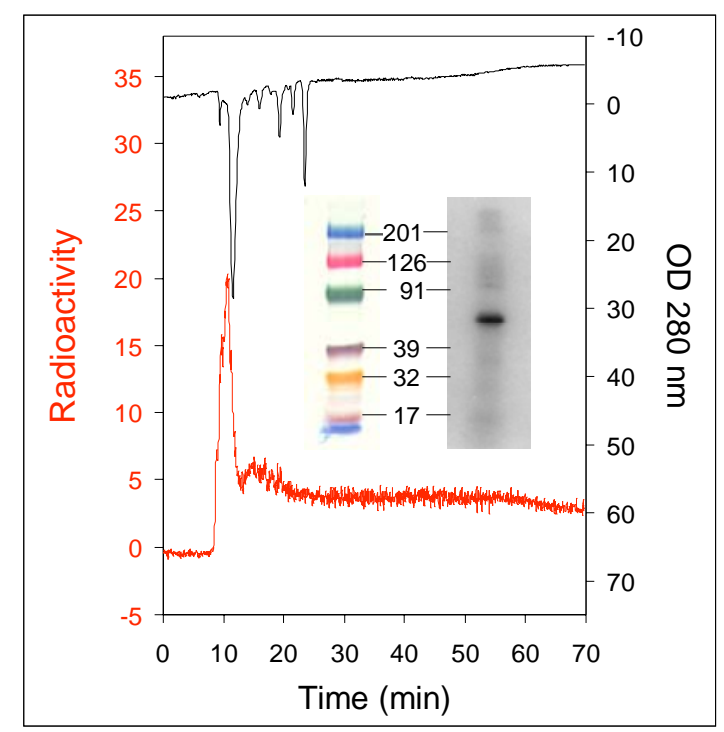

Fig. (5). Quality control analyses of ${ }^{125} \mathrm{I}-\mathrm{SHBG}$ used in biodistribution studies. HPLC of ${ }^{125} \mathrm{I}-\mathrm{SHBG}$ was done on the size exclusion column. (red trace is from the radioactivity detector; black is from the UV detector). The inset is the SDS-PAGE autoradiogram alongside the molecular weight markers. The radioactive band (black) corresponds to ${ }^{125} \mathrm{I}$-SHBG. radioactive material elutes at the retention time, which corresponds to the molecular weight of the original material. This chromatographic property indicates that the size of the protein is not affected by the radioiodination procedure. The inset is the autoradiography of the gel (SDS-PAGE) run under denaturating conditions. Color bands are the molecular weight markers run alongside the ${ }^{125}$ I-SHBG aliquot. The SDS-PAGE autoradiogram shows a single radioactive protein band with a molecular weight of approximately 45,000 corresponding to one-half subunit of the SHBG homodimer. The HPLC and SDS-PAGE data confirm that intact SHBG was recovered after radioiodination.

Biodistribution was conducted in athymic mice bearing OVCAR-3 IP xenografts and age-matched control mice without tumors. ${ }^{125}$ I-SHBG was injected IP in PBS containing $0.1 \%$ mouse serum. Groups of mice were killed at $1 \mathrm{~h}$ and $24 \mathrm{~h}$ after administration of the radiotracer. Fig. (6A) and $(\mathbf{6 B})$ show the uptake of ${ }^{125}$ I-SHBG in several normal tissues and blood expressed as a percent-injected dose per gram tissue. There were no significant differences in normal tissue uptake between tumor carrying and control mice with the exception of uterus and adrenals. Uterus dissected from the control mice at $1 \mathrm{~h}$ retained $2.48 \pm 0.67 \% \mathrm{ID} / \mathrm{g}$ compared to $1.10 \pm 0.11 \% \mathrm{ID} / \mathrm{g}$ in OVCAR-3-bearing mice $(P=0.04)$. At $24 \mathrm{~h}$ after administration, the uptake in both groups was identical at $0.87 \pm 0.12 \% \mathrm{ID} / \mathrm{g}$. Although there is a difference in the adrenal uptake, it is less prominent and at $1 \mathrm{~h}$ after administration in control mice it was recorded at $2.20 \pm 0.42 \%$ $\mathrm{ID} / \mathrm{g}$ versus $1.63 \pm 0.44 \% \mathrm{ID} / \mathrm{g}$ in OVCAR-3 mice $(P=0.16)$. The differences in the uterus and adrenals uptake are most likely attributable to the lower intraperitoneal levels of ${ }^{125} \mathrm{I}$ SHBG in OVCAR-3-bearing mice because of the uptake of ${ }^{125}$ I-SHBG by tumor cells.

Tumor uptake of ${ }^{125}$ I-SHBG and the amount of ${ }^{125} \mathrm{I}$ recovered in the peritoneal lavage are shown in Fig. (7A) and (7B). Half-lives of ${ }^{125}$ I-SHBG in tumors were estimated as $7.2 \mathrm{~h}$ and $16.8 \mathrm{~h}$ in nonadherent cancer cells and solid tumor deposits, respectively, assuming mono-exponential clearance curves. The blood clearance half-life was $\sim 30 \mathrm{~h}$ and there was no difference between the control and OVCAR-3bearing mice. At $24 \mathrm{~h}$ after administration, the supernatant from the peritoneal lavage of control mice did not contain any measurable amounts of radioactivity whereas OVCAR3-bearing mice still had $\sim 1.8 \%$ ID associated with the lavage as shown in Fig. (7B).

\section{DISCUSSION}

The biological activity of SHBG in cancer is still considered principally in the context of SHBG ability to regulate the bioavailability of sex hormones by binding them and preventing their diffusion across the cancer cell membranes. The inverse correlation of SHBG with some cancer risks is often attributed to this function of SHBG. Studies reported here reveal the stimulatory effect of SHBG on the growth of ovarian cancer in immunodeficient mice. This effect is more pronounced in older mice. In human subjects the ovarian cancer onset and risk is also agedependent, i.e., the risk for ovarian cancer increases with age. Moreover, younger patients have approximately two times higher 5-year survival rates. SHBG appears to influence the growth of solid tumors to the greater extent 


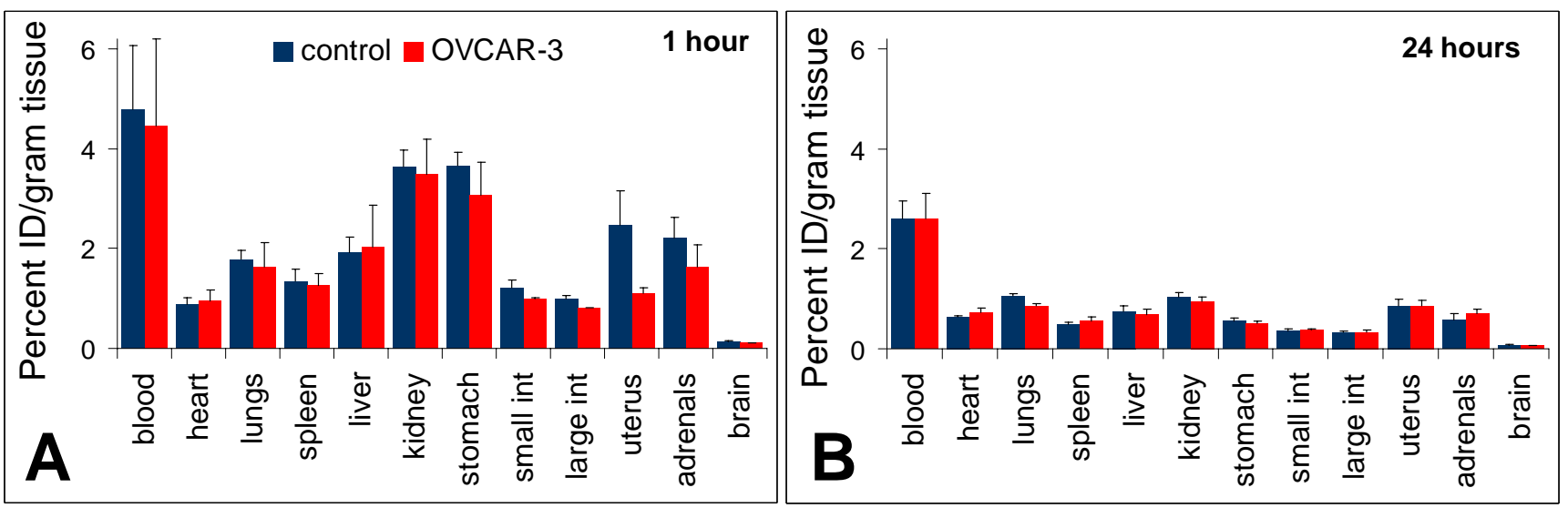

Fig. (6). Biodistribution of ${ }^{125}$ I-SHBG in normal tissues of athymic mice. OVCAR-3 cells were implanted IP and tumors were allowed to develop for 6 weeks. Control mice were age-matched. ${ }^{125} \mathrm{I}-\mathrm{SHBG}, 0.5 \mathrm{MBq} / \mathrm{mouse}$, was IP injected 45 days after OVCAR-3 implant in PBS containing $0.1 \%$ mouse serum. Biodistribution was conducted 1 hour (A) and $24 \mathrm{~h}(\mathbf{B})$ after ${ }^{125} \mathrm{I}-\mathrm{SHBG}$ administration.

than nonadherent cancer cells in peritoneal ascites. This observation is in line with the biodistribution studies of ${ }^{125} \mathrm{I}$ SHBG in OVCAR-3-bearing mice. Although the distribution of ${ }^{125}$ I-SHBG in healthy mice and OVCAR-3-bearing mice did not reveal any major differences in the uptake by normal tissues, there was a noteworthy retention of ${ }^{125}$ I-SHBG in the solid peritoneal tumors. The retention of this protein in tumor indicates that a single dose of SHBG injected

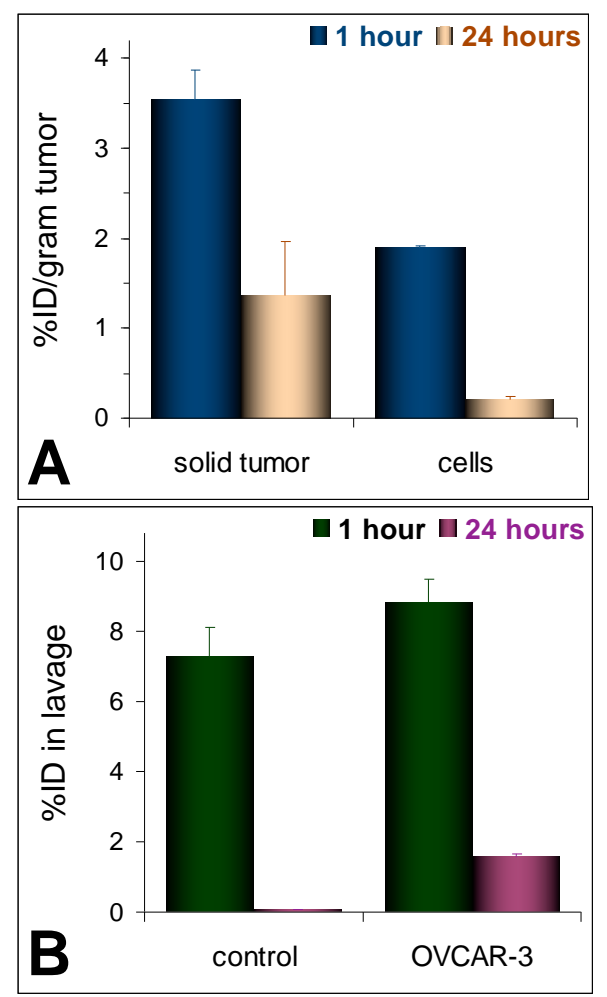

Fig. (7). ${ }^{125}$ I-SHBG uptake and retention in the peritoneal cavity and OVCAR-3 tumors. A. Percent injected dose (ID) ${ }^{125}$ I-SHBG per gram extirpated OVCAR-3 solid tumors and cells recovered in the peritoneal lavage. B. Radioactivity collected with the supernatants of the peritoneal lavage in control mice and OVCAR3-bearing mice. alongside cancer cells can have a powerful and prolonged stimulatory effect on the growth of ovarian cancer. Moreover, there is a persistent presence of the IV injected ${ }^{125}$ I-SHBG in circulation indicating the bioavailability of this protein over a period of several days. The reported half-life of ${ }^{125}$ I-SHBG in Macaca mulatta is $\sim 4$ days [21].

Adult mice livers do not produce SHBG, therefore the enhanced ovarian cancer growth when cancer cells are coinjected with SHBG, can be directly attributed to the interaction of SHBG with cancer cells. This in vivo effect of SHBG on OVCAR-3 tumors is contrary to the apparent lack of any effects of SHBG in cells grown in vitro. The disparity of SHBG effects in cells grown in vitro and in vivo suggests a possible dual role for SHBG in the regulation of ovarian carcinoma: the classic activity of this protein as the extracellular binding reservoir for testosterone and estradiol and the second function as the growth factor. In vivo studies suggest that in some tissues both forms of the sex hormone, free and bound to albumin or SHBG, may be taken up by the tissue [22]. On the other hand, in vitro SHBG is believed to keep sex steroids inactive and to participate in controling the amount of free hormones entering cells by passive diffusion $[15,16]$. Therefore, the stimulatory effects of SHBG observed in vivo are probably canceled out in vitro by the deprivation mechanisms responsible for the inhibitory activity of SHBG in cell culture [23]. Moreover, sex hormones have been shown to have either no effect on the in vitro growth of human ovarian cancer cells, despite the abundant expression of the cognate receptors [24, 25], or in some instances they exert a significant inhibitory effect $[26$, 27].

\section{CONCLUSIONS}

Sex hormone binding globulin stimulates the growth of human ovarian cancer in athymic mice. Data reported here indicate that in vitro models may be insufficient to illuminate the effects of SHBG on cancer cells in a multifactorial in vivo system. These data also indicate that the lack of SHBG in mice may be detrimental to the evaluation of the biological effects of SHBG and sex hormones in ovarian cancer, as well as in the evaluation of some anti-cancer drugs. 


\section{ACKNOWLEDGEMENT}

These studies were supported in part by the grant W81XWH-04-1-0463 awarded to JBK by the Department of Defense.

\section{REFERENCES}

[1] Platz EA, Giovannucci E. The epidemiology of sex steroid hormones and their signaling and metabolic pathways in the etiology of prostate cancer. J Steroid Biochem Mol Biol 2004; 92: 237-53.

[2] Fortunati N. Sex hormone-binding globulin: not only a transport protein. What news is around the corner? J Endocrinol Invest 1999; 22: 223-34.

[3] Hammes A, Andreassen TK, Spoelgen R, et al. Role of endocytosis in cellular uptake of sex steroids. Cell 2005; 122: 751-62.

[4] Nakhla AM, Khan MS, Rosner W. Biologically active steroids activate receptor-bound human sex hormone-binding globulin to cause $\mathrm{LNCaP}$ cells to accumulate adenosine 3,5-monophosphate. J Clin Endocrinol Metab 1990; 71: 398-404.

[5] Rosner W, Hryb DJ, Khan MS, et al. Sex hormone-binding globulin. Binding to cell membranes and generation of a second messenger. J Androl 1992; 13: 101-6.

[6] Nakhla AM, Ding VD, Khan MS, et al. 5-Androstan-3,17-diol is a hormone: stimulation of cAMP accumulation in human and dog prostate. J Clin Endocrinol Metab 1995; 80: 2259-62.

[7] Nakhla AM, Rosner W. Stimulation of prostate cancer growth by androgens and estrogens through the intermediacy of sex hormonebinding globulin. Endocrinology 1996; 137: 4126-9.

[8] Garcia-Closas M, Brinton LA, Lissowska J, et al. Ovarian cancer risk and common variation in the sex hormone-binding globulin gene: a population-based case-control study. BMC Cancer 2007; 7: 60

[9] Rinaldi S, Dossus L, Lukanova A, et al. Endogenous androgens and risk of epithelial ovarian cancer: results from the European Prospective Investigation into Cancer and Nutrition (EPIC). Cancer Epidemiol Biomarkers Prev 2007; 16: 23-9.

[10] Lukanova A, Lundin E, Akhmedkhanov A, et al. Circulating levels of sex steroid hormones and risk of ovarian cancer. Int J Cancer 2003; 104: 636-42.

[11] Lukanova A, Kaaks R. Endogenous hormones and ovarian cancer: epidemiology and current hypotheses. Cancer Epidemiol Biomarkers Prev 2005; 14: 98-107.

[12] Risch HA. Hormonal etiology of epithelial ovarian cancer, with a hypothesis concerning the role of androgens and progesterone. $\mathrm{J}$ Natl Cancer Inst 1998; 90: 1774-86.

[13] Endogenous Hormones and Breast Cancer Collaborative Group. Free estradiol and breast cancer risk in postmenopausal women: comparison of measured and calculated values. Cancer Epidemiol Biomarkers Prev 2003; 12: 1457-61.

[14] Zeleniuch-Jacquotte A, Shore RE, Koenig KL, et al. Postmenopausal levels of oestrogen, androgen, and SHBG in breast cancer: long-term results of a prospective study. Br J Cancer 2004; 90: 153-9.

[15] Costantino L, Catalano MG, Frairia R, et al. Molecular mechanisms of the D327N SHBG protective role on breast cancer development after estrogen exposure. Breast Cancer Res Treat 2008; Apr 25. [Epub ahead of print].

[16] Catalano MG, Frairia R, Boccuzzi G, Fortunati N. Sex hormonebinding globulin antagonizes the anti-apoptotic effect of estradiol in breast cancer cells. Mol Cell Endocrinol 2005; 230: 31-7.

[17] Downer JB, Jones LA, Engelbach JA, et al. Comparison of animal models for the evaluation of radiolabeled androgens. Nucl Med Biol 2001; 28: 613-26.

[18] Jänne M, Deol HK, Power SG, et al. Human sex hormone-binding globulin gene expression in transgenic mice. Mol Endocrinol 1998; 12: $123-36$

[19] Fraker PJ, Speck JC Jr. Protein and cell membrane iodinations with a sparingly soluble chloroamide, 1,3,4,6-tetrachloro-3a,6adiphrenylglycoluril. Biochem Biophys Res Commun 1978; 80: 849-57.

[20] AVMA Guidelines on Euthanasia (Formerly Report of the AVMA Panel on Euthanasia); June2007. on line http //www.avma.org/issues/animal_welfare/euthanasia.pdf (accessed August 27, 2008).

[21] Namkung PC, Stanczyk FZ, Cook MJ, et al. Half-life of plasma sex steroid-binding protein (SBP) in the primate. J Steroid Biochem 1989; 32: 675-80.

[22] Sakiyama R, Pardridge WM, Musto NA. Influx of testosteronebinding globulin $(\mathrm{TeBG})$ and TeBG-bound sex steroid hormones into rat testis and prostate. J Clin Endocrinol Metab 1988; 67: 98103.

[23] Zeginiadou T, Kortsaris AH, Koliais S, Antonoglou O. Sex hormone binding globulin inhibits strongly the uptake of estradio by human breast carcinoma cells via a deprivative mechanism. Cancer Biochem Biophys 1998; 16: 253-63.

[24] Karlan BY, Jones JL, Greenwald M, Lagasse LD. Steroid hormone effects on the proliferation of human ovarian surface epithelium in vitro. Am J Obstet Gynecol 1995; 173: 97-104.

[25] Evangelou A, Jindal SK, Brown TJ, Letarte M. Down-regulation of transforming growth factor beta receptors by androgen in ovarian cancer cells. Cancer Res 2000; 60: 929-35.

[26] Keith Bechtel M, Bonavida B. Inhibitory effects of 17beta-estradiol and progesterone on ovarian carcinoma cell proliferation: a potential role for inducible nitric oxide synthase. Gynecol Oncol 2001; 82: 127-38.

[27] Kang SK, Cheng KW, Nathwani PS, et al. Autocrine role of gonadotropin-releasing hormone and its receptor in ovarian cancer cell growth. Endocrinology 2000; 13: 297-304.

(C) Baranowska-Kortylewicz et al.; Licensee Bentham Open.

This is an open access article licensed under the terms of the Creative Commons Attribution Non-Commercial License (http://creativecommons.org/licenses/bync/3.0/), which permits unrestricted, non-commercial use, distribution and reproduction in any medium, provided the work is properly cited. 